\title{
Albania's Private School Teachers and their Stresses
}

\section{Alma Vögeli}

\section{Doi:10.5901/ajis.2015.v4n1s1p33}

Abstract

Education at private school experienced a new development after 90s as it was considered a prohibited phenomenon for approximately 50 years in Albania. This education model challenged not only the novice teachers but the more experienced ones as well. Teachers were faced with performance challenges either while with their students (in this case being the finance provider), also in front of their school leaders and educational authorities, such as Educational Directorates, who demanded standards and requirements to be accomplished by schools as well as respectively by them. While in the process of teaching an anxious teaching has some negative effects for its performance. There are some considerable evidences (Parsons, 1973, b) that anxiety can hinder the multitask performance. According to Bernstein (1983: 5), the teaching anxiety can hinder the teaching efficiency in the class, including the best or talented ones. But the teaching anxiety is not identified as disorder in the Diagnostic and Statistical Manual of Mental Disorders published by the American Psychiatric Association. The expose before the class, public speech before the class and parents alike at open meetings causes stress to novice teachers but it is also a challenge for the more experiences ones when there are challenging students with a developed intelligence in the class, as well as facing parents who require high standards for their children and their children's teachers. There are three aspects as a source of anxiety during teaching experiences: 1) Activities related to teaching prearrangement, 2) In front of students (teaching process) and 3) class placement interaction. (Gardner and Leak (1994). As a conclusion of this study it can be stated that anxiety is "a normal part of teacher's development and for this reason it is accepted as a natural element of transition from a novice teacher to a more qualified." (Harvey). The teaching anxiety, i defined as a transitional characteristic of teaching situation. It is an emotional form that is subject to change in its intensity and may disappear over growing experience.

Keywords: Anxiety, Concern, Teaching, Experience, Students, Teaching Stress

\section{Objective of the Study}

- Identification of stress and its forms to teachers of private schools in Albania

- Identification of factors that bring stress to new teachers

- The impact of stress that teachers has in the teaching process

\section{Methodology}

Study author has a considerable experience as a psychologist in private schools in Albania. During the years she has been in contact with teachers in private schools and closely studied cases of teachers and their stress impact in the process of learning. For this reason, the methodology used in the study is qualitative. Qualitative Case study Methodology Provides tools for researchers to study complex contexts their Phenomena within Baxter, P., \& Jack, S. (2008). Qualitative Case Study Methodology. Also review of the literature is another other aspect of the methodology used in the study. In Albania there are no studies on this subject. So, it will be considered foreign literature used in the study.

\section{Teachers and Stresses in the Private School in Albania}

Private schools as a prohibited phenomenon for 50 years in Albania, which was developed after the 90s, challenged not only the teachers and new educators, but also the experienced ones on the state education system.

On one side, the private schools served to open new jobs places for many teachers and their performance's challenges were increased either while with their students (in this case being the finance provider), also in front of their school leaders and educational authorities, such as Educational Directorates, who demanded standards and requirements to be accomplished by schools as well as respectively by them.

With all these requirements and challenges, the schoolteachers face stress and anxiety during their profession of teaching. These stressors were transformed over the years: from the fear of committing a political mistake while in the 
communist doctrine, to the new performance stressors with the new requirements of the education system after the 90 s. One of the teachers' stressors inside the education institutions is the personal Anxiety.

Anxiety is viewed "as a normal part of teacher development and therefore accepted as a natural element of the transition from novice to qualified teacher" (Harvey etc. 2000). Studies have shown that teachers after starting their job go through some phases on their professional development and concerns start to arise while in the process. (Fuller, 1969; Maynard and Furlong, 1993). According to Coates and Thoresen (1976:7), novice teachers report anxiety and concerns related to: a) their ability to keep the discipline on the class, b) if their students will like them, $c$ ) their knowledge about subjects and themes, d) their response if they do something by mistake or if they teach outside the specified material, e) how will they show their personality in front of others, in this case being the members of their faculty, school, parents, experienced teachers etc. The anxiety's resources are connected to: 1) requirement for more time (lack of time). Often the time spent does not fit to the financial compensation, 2) Struggle with students who are less adaptive than others, 3) the larger class with more than 32 students who should be managed by one teacher either in the primary classes or up to the high school, 4) didactic suitable materials limitation or their difficult management for various reasons such as the teaching set up, personal ability earned up until that moment etc.

Thus, the nature of concerns of novice teachers as they start their profession is different from that of more experienced teachers.

Fullers (1969) have conceptualized the teacher's concerns as progressive development, by defining them as perceived problems or concerns. According to them the concerns of candidate teachers involve a wide range. In 1975 Fuller and Bown elaborated the Concerns Theory of 1969. They identified three phases of concerns that teacher experience on their development: 1) concern about themselves (confrontation and survival in the teaching environment, e.g. ability to manage the class, gaining the sympathy of students, finding one's place within the school's structure, understanding the expectations of the director, parents while being monitored and evaluated), 2) duty concerns (the mastering routine, tasks and everyday teachings, more involvement with the students, lack of didactic materials and time pressures), 3) concerns about their state of influence (concerns about their students' understanding of their teaching, their progress and ways they can further improve the actual progress, e.g. by understanding the social and emotional needs of the students, by being fair with each single one of them, by acknowledging the effect of teaching for individual students and by being able to individualize the teaching by content selection as well as increase the intellectual and emotional growth based on the learning and student's motivation struggles. These concerns develop into progressive phases and are changes from concerns about oneself to concerns about a teacher's influence to its student. They later have concerns about their survival, such as inefficiency as teachers, their position in the class and their ability to maintain discipline. This is not up until the final phase, since at this phase their concern is focused on their student's achievements (Fuller, 1969; Coates \& Thoresen, 1976).

Other authors, Maynard and Furlong (1993), identified five phases of teachers' development: 1) early idealization, occurring before the start of school experience, 2) the survival, which appears after the novice teachers start their school experience. At this phase the class's reality replaces the previous idealization. The main focus becomes the class's control and management, school adaption and being shaped as a teacher, 3) the acknowledgement of difficulties, which occurs after the novice teachers survive the primary adaption of teaching realities. They become aware and sensible toward various tasks given to them. They often think on evaluating their way of teaching and ask themselves whether they will be appreciated, thus they want to perform a good teaching. This fact makes them focus on teaching manuals and methods, 4) after teachers have learned how to manage their classes and after they've identified what should and should not be done in the class. In this phase they often experience problems and their focus on the students' needs replaces focus on themselves and 5) the movement, which occurs when students can make this change and for this reason they can focus on the students' needs and experiment with their teaching.

Thus, the teacher's concerns before the start of their profession develop progressively into different phases of development. In general, concerns tend to focus into the class' management and organization, to later move on to the direction of pedagogy and subject, and in the end return to the students learning and academic duties (Lidstone and Hollingsworth, 1990). Among the identified concerns it is pretended that the survival issues show up before the teaching concerns and they belong to the process of becoming whole as a teacher, class management, mastering the appropriate and sufficient knowledge and fulfilling the expectations of parents and supervisors.

Maynard and Furlong (1993) likewise Fuller and Bown (1975) suggested that development is sequential, thus teachers go through concerns or development states before they are willing to face the next concern or development phase. Other studies have agreed with the fact that concerns arise during their development as teachers. The study of Richards and Gipe (1987) on "Reflective Concerns of Prospective Teachers in an Early Field Placement" supported 
Fuller's researches. Richards and Gipe found out that Most of the statements written at the very beginning of the semester reflected concerns with self-adequacies. At the beginning of development phase, the teachers concerns were mainly for survival and self-oriented. Most of the statements written near the semester's end reflected concerns for students and for the teaching profession.

Guillaume and Rudney (1993) identified a wide range of concerns which they grouped into six broad categories: lesson planning and evaluation; discipline; working with pupils; working with co-operating teachers and adjusting to their classrooms; working with others in the profession and transitions from student to professional teacher. The nature of the concerns and the emphasis within each category was found to shift as students developed towards independence, changing from the role of student to taking on the role of the teacher, e.g. students' views of lesson planning and of evaluation changed from a narrow to a broader focus, suggesting an expansion in thinking; students' concerns about discipline changed from focusing on using specific techniques to building a relationship with their pupils based on legitimate authority. Guillaume and Rudney (1993) suggested that a) students hold different concerns at the same time, b) there is a change in nature of concerns over time in their development from students to teacher, c) although students develop over the course of their initial teacher education course, their concerns are not sequential. Students become more concerned in regards to various aspects of their way of being taught. (Guillaume and Rudney, 1993)

In some studies it is embraced the idea that teaching concerns arise consecutively in some development phases, whereas in some other studies is it reasoned that the appearance of concern in teachers prior to the start of their profession is complex and cannot be reduced to a linear progression. (Bullough, 1997). The study of Pigge \& Marso (1987) shows a small support of the sequence of changes' development of concerns defined by Fuller.

\section{Children's and Adult's Stress and Its Symptoms}

Either adults or children are stress victims, and it come and goes invisibly. Nowadays the rhythm of life is fast and changes are happen frequently and quickly. There are various factors increasing stress in childhood. David Elkind, author of "The Hurried Child" supports the idea that stress is inherent in life. He adds that one of the most important factors of stress to children is the hurry to get ready, to go from a place to the other, reach success and grow. Worries and concerns arising within the family in the cases of death, divorce, health problems, tension and fight cause fear, anxiety, and affective tension and contribute to a chronic stress.

According to Harold Minden, Psych Professor and specialist in the stress area, stress can damage physical, affective, social, intellectual well-being and the school performance in childhood. It can influence motivation, concentration, perception, memory and the process of learning. Each child reacts toward stress on its own way. As adult alike the child has various capacities to tame this phenomenon. Besides, a stress source for a child may be different from another.

Some of the stress symptoms in children or even in the adults who have to share their speech publicly or give a presentation for their enterprise are:

1. Continuous Neck pain, headache, abdominal pain

2. Irritation, desperation, increasing anger

3. Unusual calmness

4. Difficulty in sleeping or relaxing

5. Hibernation, dreams, absence in various activities

6. Hyper energy or nervousness, hands or body shaking or frown

7. Difficulty in understanding friends

Even though the above symptoms are mentioned for children, the adults have the same symptoms but which seem more camouflaged.

Anxiety is one of the common human states that we all face one moment or another, or in various situations. Fears and concerns are common in each one of us and this is a normal part of human development. Some people experience anxiety about events or things unnecessarily more than others. Even though psychologists or other professionals of the field try to give an explanation to the fact that why people experience more fears and anxiety than others, by orienting to people's childhood or request of performance, their studies often remain with unconvincing answers.

Physical symptoms of anxiety are present in every fear or provocation situation. These symptoms may include: frequent or abnormal heartbeats, sweating, shaking, a feeling of breathing constriction, a feeling of chocking, chest pain, discomfort, abdominal pain or nausea, dizziness, feeling of insecurity, faint, numbness, pins and needles, fever or high temperature. (American Psychiatric Society 2000: 432). Anxiety is related to the severity of threat (Keavney and Sinclair, 
1978). In the education context, anxiety may be the reaction of a teacher toward what he percepts it as a threatening or unmanageable environment.

Sigmund Freud has been accepted in general as the first psychoanalyst who made efforts in explaining the meaning of anxiety in the context of psychological theory. Freud (1936), considered anxiety as the "feeling of something", an unpleasing emotional state followed by physiological conditions such as: frequent heart beatings, nausea, muscle tension, dizziness and breathing difficulties. According to him, the experienced anxiety from normal people was qualitatively different from the neurosis anxiety. The everyday life anxiety, which he called the "realistic" or "objective" anxiety" refers to certain objects out in the real world and is a synonym of what is usually known as fear.

Sarason (1986) defines anxiety as: "disturbing concern due to approaching events" (pg 21). He has defined the anxiety reaction characteristics and situations it is experienced:

1. Situation considered as difficult, challenging and threatening.

2. Individual sees himself as inadequate in treatment or inappropriate.

3. Individual focuses in unpleasant consequences or personal incapability.

4. Individual competes in activities of important cognitive tasks.

5. Individual expects and predicts failure or loss related to others.

\section{Teaching Anxiety}

During my experience in institutions and private schools, I can clearly notice that novice teachers or educators who just came out of classes and have an image on their own about how the school, class or even the students should be. It is not easy for them to adapt with situations that come out of the schemes that they have projected on their minds. Also the non management or fear of failing makes them even more stressful and their anxiety level within them starts to increase, even when the situations are easy for someone else or for someone with more experience in the profession.

Sinclair pretends that the stimulating situations, who cause anxiety reactions, are supposed to be such when the individual predicts a strong threat, in regards to his self-respect... the anxiety reactions are like a signal to get the two answers: important ... and not important either for the learning or task performance. It is stated that the answers for important tasks are accompanied with an increase of efforts; concentration and procedural strategies, previously found for the ease of learning and diminish anxiety. Whereas the answers of the not important task relate to failing consequences, or the absorption of self-underestimation and protective ego, avoiding projected answers and to protect the individual from loosing respect.

The answers of important tasks compete those of not important ones and typically have an effective intervention in learning and performance. (pg 97-98). The teaching anxiety is defined as a transitional characteristic of teaching situation. It is an emotional form that may change its intensity and disappear with the experience (Williams, 1991). This emotional form of anxiety is related with each aspect of what the teacher does in class, as well as with other school activities. Gardner and Leak (1994) indentified the teaching anxiety too as anxiety experienced with teaching activities and that has to do with the preparation and activities in the class (pg.28). They supported the teaching anxiety definition in the Bernstein work (1983), who wrote a classic essay exploring in his experience of teaching anxiety. Bernstein emphasized that during the experience of teaching anxiety there are three components: physiologic awakening, subjective concerns and behavior division (pg.5). These are known and common components that are related to anxiety in general. (Bernstein, 1983).

The teaching anxiety is not identified as a disorder in the Diagnostic and Statistical Manual of Mental Disorders of the Psychiatric American Society. Such disorders are classified as anxiety disorders: panic disorder, post traumatic stress disorder, Stress acute disorder, anxiety disorders related to conditions of certain physical or health problems, anxiety disorders. (Psychiatric American Society, 2000)

Coates and Thoresen (1976: 17), presented a summary of the teaching anxiety literature and offered a general view of the teaching anxiety stating:

Even the more experienced teachers have experienced anxiety and fear in front of their class (Ford, 1993). many teachers write words of concern: "I am not doing it right", "I am not effective", "I have a lack of time to do my job right", I show "limited productivity" and "I do not have a qualitative time to make a positive impact to the students. (Hargreaves, 2003). They admit the existence of "less effective instructions", dissatisfaction in having "a little time for themselves" and "a little time for their students" or "helping students in need". Hargreaves emphasizes that "keeping high standards in class as a teacher with little time ... to prepare, becomes a great source of anxiety" (pg.144). Reactions to various concerns can be in the function of variables such as: personality, gender and culture. 
According to Morton (1997),"students to teacher in one place can differently percept the concerns from students to teacher of another place. Also "students to male teachers react differently toward the specific concerns of teaching experience of female students." (pg.70)

\section{Some Anxiety Effects}

Teaching anxiety is specific to teaching task (Keavney and Sinclair, 1978) and the anxious teacher's efficiency is affected. There are considerable evidences (Parsons, 1973, b), that anxiety can hinder the multitask performance. According to Bernstein (1983: 5), the teaching anxiety can hinder the teacher's efficiency in the class, including those who are the best and more talented ones.

The exposure in front of the class, public speech either in front of the class or in front of the parents in open meetings, causes them stress and it has anxiety consequences for the novice teachers, but it is also a challenge for the more experienced ones, when in the class there are challenging students who have a developed intelligence as well as confronting parents who have high demands for their children and their teachers.

The exposure in front of the class (Fraher, 1984) is the beginning of a new way, with mysteries involving communication contrary to the actual knowledge possession. When an individual speaks in public is exposed to other people's judging. The situations in which someone feels judged by others can cause negative feelings. The fear of speaking in public is considered as an important source of anxiety (Cano-Vindel and Miguel-Tobal 1999). Bodie (2010) argues than "the public speaking competence is key factor for student's success inside and outside class" and that public speaking is "a necessary part of job responsibilities" (pg.71).

He then further explained some specifics of teaching anxiety, that result into a lack of efficiency in the class, problems that can be attributed to teaching anxiety:

1. Inability of clear thinking (being confused, or taking to long to give answers.)

2. Continuous negative interactions with students (sarcasm toward the students' questions, inappropriate comments or negative observations at students' abilities, interests and motivations).

3. Practicing models and avoidance tactics (inappropriate job schedule by being "too busy" to talk to students after the class, lack of preparation)

4. Building "too soft" or "too harsh" relationships with students (insisting on demanding respect from students, a clear effort to have students at one's favor by means of simple exams, expression of lack of interest regarding scores.

5. The exposure of "multiple personality" (reasonable type of person, calm, relaxed and compassionate in most of the cases, but defensive hostile and tough in the class.

6. Showing distrustful thinking (the idea that students have fun in making me look stupid)

In their study, Keavney and Sinclair (1978) emphasize that teaching anxiety can negatively affect the survival of the teaching profession, in their emotional impact, in their approach and the styles of dealing with it.

$\Rightarrow$ In the survival conditions of teaching profession, teachers who drew from teaching were characterized by anxiety. Thus, many other teachers who had not started their profession yet, experienced anxiety, did not continue their teaching career, after finishing their teacher trainings.

$\Rightarrow$ In the teaching conditions, the emotional impact of the anxiety can affect the class atmosphere, reducing the students' learning motivation, the creation of warm relationships and verbal support between teachers and students. On the other side, this may increase the students' anxiety resulting in hostility between students and teachers.

$\Rightarrow$ The study found out that there has been a negative relationship between teaching anxiety and students' achievements.

According to Ameen etc (2002) teaching anxiety can negatively affect the teachers: unpleasant situations at work and career, difficulty in responding to protective teaching measurements and the development of a certain personality in the class in which the teachers seem cold or soft and are distrustful about the student's motives and objectives. Instructors suffering from teaching anxiety, try to develop a specific teaching personality (Bernstein, 1983). Coates and Thoresen (1976) have reported a strong positive correlation between the teacher and students' stress. If the students see their teacher concerned, a negative influence on their behavior may occur. The increase of negative influence can attribute to an increase anxiety level at the teachers. This mutual transfer has its effect among students and their teacher, by creating unbalanced dynamics in the class. 


\section{Causes of Teaching Anxiety}

There have been quantitative and qualitative studies (Gardner and Leak, 1994; Morton etj., 1997; Sorenson and Halpert, 1968) based on surveys, observations and professional considerations to define the factors influencing the birth of anxiety to students during teaching in real class situation. These studies emphasize that high level of anxiety during teaching of students for teachers, is a common phenomenon and anxiety is related to various teaching aspects.

On their study, Gardner and Leak (1994), suggested three aspects which can be a source of anxiety during teaching experiences: 1) Activities on teaching preparations, 2) Coming in front of students (teaching process) and 3) class placement interaction. According to them the intensity of the anxiety of surveyed individuals "is positively connected to some situation variables, such as teaching from unknown materials. [...] students who bring new facts [...], and when they have negative experiences with a certain class.

Morton etc. (1997) used Hart's Student Teacher Anxiety Scale -STAS for their study, which produced four anxiety factors on its factorial analysis which were named: evaluation anxiety, pedagogic anxiety, class management anxiety and staff relationship anxiety.

On the study performed by Sorenson and Halpert (1968), there were five identified factors that were contributing to the teaching anxiety: 1) nervousness, 2) insecurity characterized by the personal inadequacy feeling, 3) disagreements especially to cooperate with teachers, 4) changes of personalities between students and teachers, 5) problems with discipline and being liked by students (pg. 30-31)

\section{Supervisors / Teachers' Observation and Evaluation Anxiety}

The anxiety caused by being observed it refers to the observation of lector or teacher who is the supervisor. On his study Capel (1997) used the Hart questionnaire with a team of students from south England and found out that the main cause of stress at the students was evaluation and observation. Students for teachers often complained that they would forget the contents and that they would feel nervous when the teacher sat in the back of the class and watched over them. The "doing things right" pressure, as well as class management made them tense and concerned during teaching. The most difficult occurrences of the teaching experiences were remarks and evaluations performed by the University's supervisors, whereas the less tense experiences include the general interactions with the school personnel. Some students are able to overcome this state in one or two days, but for others this served as a barrier to gain full self confidence. (Capel, 1997).

During the experiences in the field it has been noted that the majority of students for teachers are concerned regarding evaluation (Capel, 1997, Morton etc. 1997). The evaluation by supervisors / teachers is a concerning issue for students for teachers and is called "Evaluation Anxiety". Gabriel (1957) in his study "An analysis on emotional problems of teachers in the class" came out with the conclusion that teaching anxiety is connected to the evaluation of inspectors.

The conclusions from the observations in the field, as well as previous studies on this matter, show us that stressors of novice teachers are more noticeable due to little experience or the unprocessed theoretic image and not adapting to practice. Over the years this image changes even though it shows up while being audited by the Education Directorates of respective districts. The desire to always show the positive and stronger side, makes the teachers sensible to expose that other side which is less positive and as result they are accompanied by the fears of challenge and failures.

\section{References}

Albusaidi, A. \& Aldhafri, S. (2009). Validation of the Teaching Anxiety Scale (TCHAS (1) - (29) for the Omani Context. Paper presented at the 54 International Council on Education for Teaching, Muscat, Sultanate of Oman.

Al-Mehrzi, R., Al-Busaidi, S., Ambusaidi, S., Osman, M., Amat, M., \& Al-Ghafri, S., (2011) Path Analysis of the Effects of Teaching Attitudes and Anxiety on Pre-Service Teachers" Efficacy Beliefs. World Applied Sciences Journal 14 (Learning Innovation and Intervention for Diverse Learners): 52-59, 2011. ISSN 1818-4952

Ameen, E. C., Guffey, \& Jackson, C. (2002). "Evidence of Teaching Anxiety Among Accounting Educators." Journal of Education for Business 78.1, 16-22. American Psychiatric Association. (2000). Diagnostic and Statistical Manual of Mental Disorders. (Text Revision - 4th ed.). Washington, DC: American Psychiatric Association.

Ankers, A. M., Llamas, J. M., \& Tomyoy, C. (2005). Impact of preservice student teaching experience on urban school teachers. Journal of Olnstructional Psychology, 32(1), 82-98. 
Armor, D., Conroy-Oseguera, P., Cox, M., King, N., McDonnell, L., Pascal, A., et al. (1976). Analysis of the school preferred reading programs in selected Los Angeles minority schools (Report No. R-2007-LAUSD). Santa Monica, CA: RAND. (ERIC Document Reproduction Service No. 130 243).

Asthon, P. T. (1984). Teacher efficacy: A motivational paradigm for effective teacher education.

Ashton, P.T., \& Webb, R.B. (1982, March). Teachers sense of efficacy: Toward and ecological model. Paper presented at the annual meeting of the American Educational Research Association, New York

Ashton, P.T., \& Webb, R.B. (1986). Making a difference: Teachers" sense of efficacy and student achievement. New York: Longman.

Ashton, P.T., Olejnik, S., Crocker, L., \& McAuliffe, M. (1982, April). Measurement problems in the study of teachers" sense of efficacy. Paper presented at the Annual Meeting of the American Educational Research Association, New York.

Azar, A. (2010). In-service and Pre-service Secondary Science Teachers" Self-Efficacy Beliefs About Science Teaching. Educational Research and Reviews, 5(4), 175-188. Retrieved January 19, 2010 from http://www.academicjournals.org/ERR2

Ball, D. L., \& Cohen, D. K. (1999). Developing practice, developing practitioners: Toward a practicebased theory of professional education. In G. Sykes and L. Darling-Hammond (Eds.), Teaching 135 as the learning profession: Handbook of policy and practice (pp. 3-32). San Francisco: Jossey Bass.

Bandura, A. (1977b). Self-efficacy: Toward a unifying theory of behavioral change, behaviors. Psychological Report, 63, $407-414$.

Bandura, A. (1986). Social Foundations of Thought and Action: A Social Cognitive Theory. Englewood Cliffs, NJ: Prentice-Hall.

Bandura, A. (1997). Self-efficacy: The exercise of control. New York: W. H. Freeman.

Bandura, A. (1999). Social cognitive theory of personality. In Pervn, L., \& John, O. (Eds), Handbook of personality theory and research (pp. 154-196). New York: The Guilford Press.

Bernstein, D. (1983). Dealing with teaching anxiety: A personal view. Journal of the National Association of Colleges and Teachers of Agriculture, 27, 4-7.

Bodie, G. D. (2010). A Racing Heart, Rattling Knees, and Ruminative Thoughts: Defining, Explaining, and Treating Public Speaking Anxiety. Communication Education, 59, 70-105.

Borko, H., \& Mayfield, V. (1995). The roles of the cooperating teacher and university supervisor in learning to teach. Teaching and Teacher Education, 11(5), 501-518.

Bright, G. (1994). Changes in undergraduate preservice teachers, beliefs during an elementary teacher-certification program. Speeches/Meeting Papers. (ERIC Documentation Service No. ED375087).

Brouwer, N. \& Korthagen, F. (2005). Can teacher education make a difference? American Educational Research Journal, 42, $153-224$.

Brown, R., \& Gibson, S. (1982, April). Teachers" sense of efficacy: Changes due to experience. Paper presented at the annual meeting of the California Educational Research Association, Sacramento, CA

Bullough, R. V. (1997). Becoming a teacher: self and the social location of teacher education. In B. J.

Biddle, T. L. Good and I. F. Goodson (Eds.). The international handbook of teachers and teaching (pp. 79-134). Dordrecht, Netherlands: Kluwer

Burns, R. (1991). "Personal development in teacher education programmes". In Australian Educational Researcher, 18, (1), 97-109.

Caires, S., \& Almeida, L. S. (2005). Teaching practice in initial teacher education: Its impact on student teachers" professional skills and development. Journal of Education for Teaching, 31(2), 111-120.136

Campbell, D. \& Stanley, J. (1963). Experimental and quasi-experimental designs for research. Chicago, IL: RAND-McNally.

Cano-Vindel. A., \& Miguel-Tobal J.J. (1999): "Rating, coping and anxiety, "Anxiety and Stress 5 (2-3), pp. 129-143.

Capa, Y. (2005). Factors influencing first-year teachers' sense of efficacy. Unpublished doctoral dissertation, The Ohio State University.

Capel, S. (1997). Changes in students' anxieties and concerns after their first and second teaching practices. Educational Research. 39, 211-228.

Caprara, G., Barbaranelli, C., Steca, p., Malone, P. (2006). Teachers' self-efficacy beliefs as determinants of job satisfaction and students' academic achievement: A study at the school level. Journal of School Psychology, 44, 473-490.

Castillo, J. J. (2009). Convenience sampling. Retrieved on November 20, 2010 from Experiment Resources: http://www.experimentresources.com/convenience-sampling.html

Cerit, Y. (2007). Classroom teachers' levels of self-efficacy beliefs. Hacettepe University Congress. Primary education Continuing Education and Training, Ankara, Turkey.

Chan, K. W., \& Leung, M. T. (1998). Hong Kong preservice teachers" focus of concerns and confidence to teach - A perspective of teacher development. Online proceedings of the

Australian Association for Research in Education (AARE), Adelaide, Australia. Retrieved September 6, 2007, from http://www.aare.edu. au/98pap/cha $98367 . h t m$

Cheung, H.Y. \& Hui, S.K.F. (2011) Teaching Anxiety amongst Hong Kong and Shanghai In-Service Teachers: The Impact of Trait Anxiety and Self-Esteem. Asia-Pacific Education Researcher, 20(2), 395-409

Clandinin, D. J., \& Connelly, F. M. (2000). Narrative inquiry: Experience and story in qualitative research. San Francisco, CA: JosseyBass.

Coates, T. J., \& Thoreson, C.E. (Spring, 1976). Teacher anxiety: A review with recommendation. Review of Educational Research, , 46, 159-184

Cohen, J.W. (1988) Statistical power analysis for the behavioural sciences (2nd edn). Hillsdale, NJ: Lawrence Erlbaum Associates

Cohen, L., Manion, L., \& Morrison, K., (2000) (5th Edition), Research Methods in Education, London: Routledge Falmer 
Cole, A. L., \& Knowles, J. G. (1993). Shattered images: Understanding expectations and realities of field experiences. Teaching and Teacher Education, 9(5/6), 457-471.137

Conant, J. B. (1963). The education of American teachers. New York: McGraw-Hill Book Company, Inc.

Cook, T. D., \& Campbell, D. T. (1979). Quasi-experimentation: Design and analysis issues for field settings. Boston, MA: Houghton Mifflin Company.

Corrigan, D. C. (Summer, 1974). The future: Implications for the preparation of education personnel. The Journal of Teacher Education, $25,100-107$

Creswell, J. W. (2008). Narrative research designs. In Educational research: Planning, conducting and evaluating quantitative and qualitative research (3rd ed., pp. 511-550). Upper Saddle River, NJ: Pearson Education, Inc.

Davis, E.A., Petish, D., \& Smithey, J. (2006). Challenges new science teachers face. Review of Educational Research, 93, 189-217

Davis, J. A. (1971). Elementary survey analysis. Englewood Cliffs, NJ: Prentice Hall.

Dethier, B. (1999). The Composition Instructor"s Survival Guide. Portsmouth: Boynton/Cook. D'Rozario, V. \& Wong, A. (1996). A study of practicum-related stresses in a sample of first yearstudent teachers in Singapore. Paper presented at the annual conference of the Singapore Educational Research Association and Australian Association for Research in Education, Singapore, 25-29 November 1996.

Edwards, J. L., Green, K. E., \& Lyons, C. A. (April, 1996). Teacher efficacy and school and teacher characteristics. Paper presented at the mannual meeting of the American Educational Research Association, New York, NY.

Elsworth, GR \& Coulter, F. (August, 1977). Aspiration and attainment: The measurement of professional self-perception in student teachers. Hawthorn,Victoria: Australian Council for Educational Research. Occasional paper N. 11.

Evans, E. D., \& Tribble, M. (1986). Perceived teaching problems, self-efficacy and commitment to teaching among preservice teachers. Journal of Educational Research, 80(2), 81-85.

Farrell, T. (2002). Learning to teach English language during the first year: Personal influences and challenges. Teacher and Teacher Education. 19 (2003) 95III.

Farrell, T. (2008). „Here"s the book, go teach the class" ELT practicum support.

Field, A. (2005). Discovering statistics: Using SPSS for windows. London: SAGE Publications

Fish, T. A. \& Fraser, I. H. (2001). Exposing the iceberg of teaching anxiety: a survey of faculty at three New Brunswick Universities. Electronic Journal of the American Association of 138 Behavioral and Social Sciences, 4. Retrieved April 8, 2008 from the World Wide Web at: http://www.aabss.org/journal2001/Fish2001.jmm.html

Fives, H. \& Buehl, M. (2010). Examining the Factor Structure of the Teachers" Sense of Efficacy Scale. The Journal of Experimental Education, 78, 118-134

Fives, H., Hamman, D., \& Olivarez, A. (2007). Does burnout begin with student teaching? Analyzing efficacy, burnout, and support during the studentteaching semester. Teaching and Teacher

Education, 23(6), 916-934.

Ford, CT. (1993). Teaching from the heart. University Affairs , 34 (3), 12 - 13.

Fortman, C. K., \& Pontius, R. (2000). Self-Efficacy during Student Teaching., Paper presented at the Annual Meeting of the Mid-Western Educational Research Association (Chicago, IL, October 25-28, 2000). Page Length: 13(SM) ED447103

Fraenkel, J. R., \& Wallen, N. E. (2003). How to design and evaluate research in education. New York, NY: McGraw-Hill.

Fraher, R. (1984). "Learning a New Art: Suggestions for Beginning Teachers." The Art and Craft of Teaching. Ed. Margaret Morganroth Gullette. Cambridge: Harvard UP, 116-127

Freud, S. (1936). The Problem of Anxiety. New York, W. W. Norton.

Fuller, F. F.(1969). Concerns of teachers: A developmental conceptualization. American Educational Research Journal, 6, $207-226$.

Fuller, F.F. and Bown, O.H. (1975). Becoming a Teacher, in K.J. Rehage (Ed.) Teacher Education, NSSE 74-th Yearbook, part II, Chicago: University of Chicago Press

Gabriel, J. (1957)An analysis of the emotional problems of teachers in the classroom. London: Angus and Robertson, Ltd.

Gall, J. P., Gall, M. D., \& Borg, W. R. (2005). Applying educational research: A practical guide. Boston: Pearson Education, Inc.

Gall, M.D., Borg, W. R., \& Gail, J.P. (1996). Educational research: An introduction ( 6th ed.) White Plains, NY: Longman

Gardener, L. E. \& Leak, G. K. (1994). Characteristics and correlates of teaching anxiety among college psychology teachers. Teaching of Psychology, 21(1), 28 -32.

Gay, L. R. (2000). Educational research: Competencies for analysis and application. (6th ed.). Upper Saddle River, NJ: Prentice-Hall.

Ghaith, G., \& Shaaban, K. (1999). The relationship between perceptions of teaching concerns, teacher efficacy, and selected teacher characteristics. Teaching and Teacher Education, 15(5), 487-496.139

Gibson, S., \& Dembo, M. H. (1984). Teacher efficacy: A construct validation. Journal of Educational Psychology, 76(4), 503-511.

Ornel Bilali Shkencave-Sociale-Departament-Psikologji/http://www.doktoratura.unitir.edu.al/wp-content/uploads/2013/12/

Glesne, C. (1999). Becoming qualitative reserchers: An introduction ( 2th ed.) New York: Addison Greenwood, G. E., Olejnik, S. F., \& Parkay, F. W. (1990). Relationships between four teacher efficacy belief patterns and selected teacher characteristics. Journal of Research and Development in Education, 23(2), 102-107.

Gregory, A. (1976). The effect of student teaching on the professional self-concept of student teachers. A study of student teachers in the professional development program, Simon Fraser University. Doctoral thesis. Simon Fraser University, 